\title{
Sustainable Energy Investment through Paradiplomacy Practices in South Sulawesi, Indonesia
}

\author{
Ahmad Harakan ${ }^{1, *}$, Nuryanti Mustari ${ }^{2}$, and Abel Alfred Kinyondo ${ }^{1}$ \\ ${ }^{1}$ Universitas Muhammadiyah Makassar, 90221, Makassar, Indonesia \\ ${ }^{2}$ University of Dar es Salaam, TZ-01, Dar Es Salaam, Tanzania
}

\begin{abstract}
The use of energy in developing countries is marked by the government's involvement in realizing the transfer of energy use from conventional to renewable. This involvement is in line with the sustainable development Goals program, which emphasizes the need for action in using environmentally friendly and sustainable energy in the implementation of development. The correct option in realizing the dominance of renewable energy is through investment and cooperation with partners from abroad who have experience and knowledge in the use of renewable energy. Independent investment and cooperation can be realized with paradiplomacy practices carried out by local governments. The research and dissemination of ideas in this article aim to discuss the dynamics of renewable energy investment in paradiplomacy practices. Research with the theme of paradiplomacy uses qualitative research through in-depth and relevant case studies. The technique of determining informants was carried out by purposive sampling through key persons, by determining which groups of participants became informants according to the selected criteria relevant to the research problem. Observation, interview, and documentation are data and information collection techniques in this study. The support of the central government and local governments is manifested in the availability of regulations, permits that are not complicated, and relevant promotions that support the realization of the use of renewable energy and transfer technology.
\end{abstract}

\section{Introduction}

Sustainable energy is related to renewable energy, both of which are essential and relevant aspects of the vision of sustainable development [1,2]. Although for developing countries, renewable energy is a new step in the implementation of development, policies and energy programs like that are the right choice amid the current situation $[3,4]$. The Government of Indonesia carries out policy options to promote the procurement of sustainable renewable energy through a series of academic analyzes and internal and external lobbying [5].

* Corresponding author: ahmad.harakan@unismuh.ac.id 
The Indonesian Government implemented the renewable and sustainable energy policy to establish a Wind Power Plant in Sidrap [6] and a similar power plant in Jeneponto [7]. Both of these areas are located in South Sulawesi. Although the Wind Power Plant project is a national project, the role of local government is also influential in the establishment of sustainable and renewable energy policy implementation [8]. At least the local government has provided the land, presented the opportunities and advantages of the region, and ensured that all project implementations run as they should. Sustainable energy development has stable performance and prospects [9].

The role and strategic steps of local government in the realization of the project in scientific conceptualization are called Paradiplomacy [10]. Specifically, because the local government acts as a provider and participates in promotions to attract investors on sustainable energy, these activities can be embedded as a form of investment paradiplomacy [11].

\section{Method}

This study on paradiplomacy employs qualitative research methods in the form of a complete tracking study. Purposive sampling through key persons was used to identify informants, with a set of participants chosen based on factors related to the research subject. In this study, data and information were gathered through observation, interviews, and documentation. An in-depth interview using a semi-structured approach to identify problems more freely and gaining information from someone by asking questions based on the study objectives is employed. The flow of actions that have been completed, including data collecting, data reduction, display, and drawing conclusions or verification, is referred to as data analysis.

\section{Result and Discussion}

The development of infrastructure for renewable and sustainable energy projects such as wind power plants as a national energy sector should at least begin with an in-depth SWOT analysis [12]. In-depth SWOT analysis and precise economic calculations led to realizing the first renewable and sustainable energy project in Indonesia. This first renewable and sustainable energy project is called Wind Power Plant.
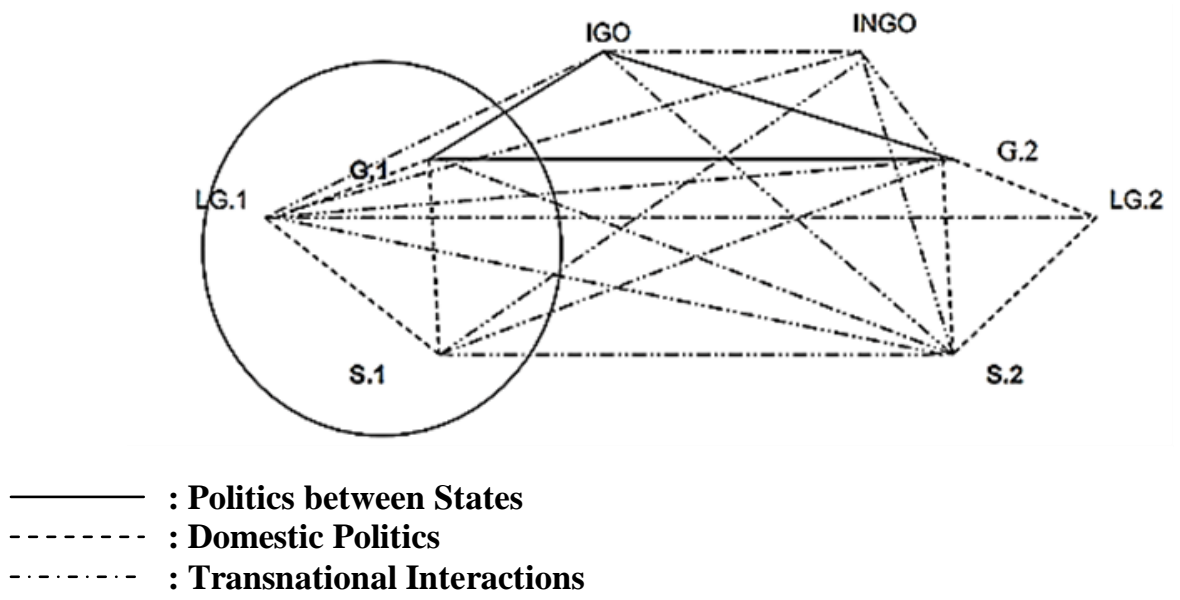

Fig. 1. The Existence of Local Governments (sub-state actors) 
The provision of infrastructure facilities and promotion of regional potential carried out by the South Sulawesi Provincial Government through the investment paradiplomacy scheme has resulted in significant capital investment to build a wind power plant in Sidrap. In addition, the granting of permits and the availability of regulations within the regional and national frameworks have supported the implementation of this project. To understand the involvement of local governments in the paradiplomacy scheme related to the realization of this project, we can see it in Figure 1.

The first wind power plant in Indonesia, located in Sidrap, South Sulawesi [6], was developed with an investment of US\$ 150 million or around Rp 2.02 trillion [13]. The developer is PT UPC Sidrap Bayu Energi, a consortium consisting of UPC Renewables Asia I, UPC Renewables Asia III, Sunedison, and Binatek Renewable Energy [13].

Part of the project's cost came from a loan from the Overseas Private Investment Corporation (OPIC), the United States government development financial institution [13]. The loan period is IDR 16.5 years, with a total loan amount of US\$ 120 million [13].

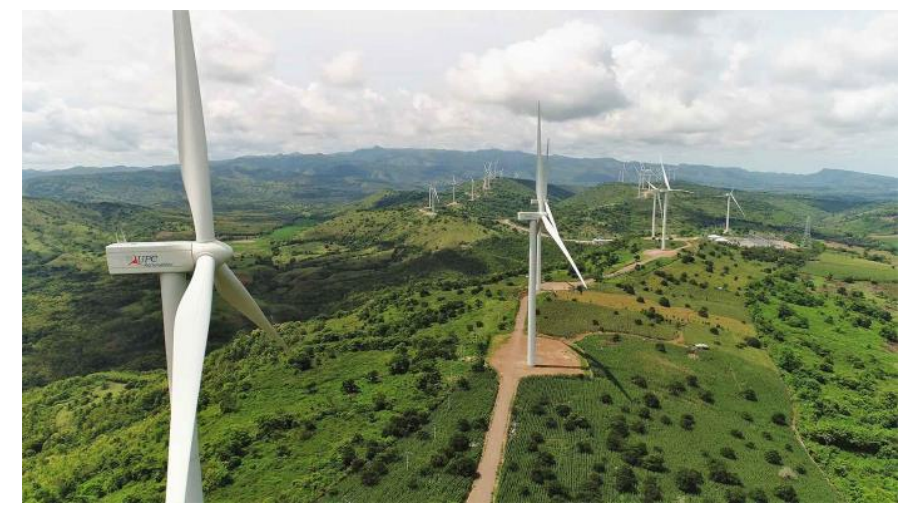

Fig. 2. Wind Power Plant in Sidrap, South Sulawesi.

There are 30 turbines for this power plant project, each with a capacity of $2.5 \mathrm{MW}$. The turbine has a height of 80 meters, and the length of the propeller is about 57 meters [14]. The technology for building power plants with renewable and sustainable insights comes from a Spanish company, Gamesa [15]. The Wind Power Plant in Sidrap will be developed again in several stages of development. A factual description of the Wind Power Plant in Sidrap, South Sulawesi can be seen in figure 2. The Wind Power Plant in Sidrap, South Sulawesi, has a capacity of $70 \mathrm{MW}$, and the effect can illuminate 70,000 houses [6].

Another renewable and sustainable energy strategic project in Indonesia is the Wind Power Plant located in Jeneponto, South Sulawesi $[15,16]$. The existence of two strategic projects related to renewable energy and sustainability signifies the success of the Local Government in presenting the potential of the region and providing complimentary facilities for the realization of the project. The massive role of local government is in line with the concept of investment paradiplomacy [11].

This power plant, which is the target of the national energy mix, has 20 Wind Turbine Generators [WTG] with a capacity of 72 megawatts [17]. A total of 20 turbines with a length of 67 meters in PLTB Tolo Jeneponto can provide lighting for 300,000 households with 900 VA customers [17]. The presence of this power plant also fulfills green energy and broad environmental insight, does not damage ecosystems and the environment, as shown in figure 3. 


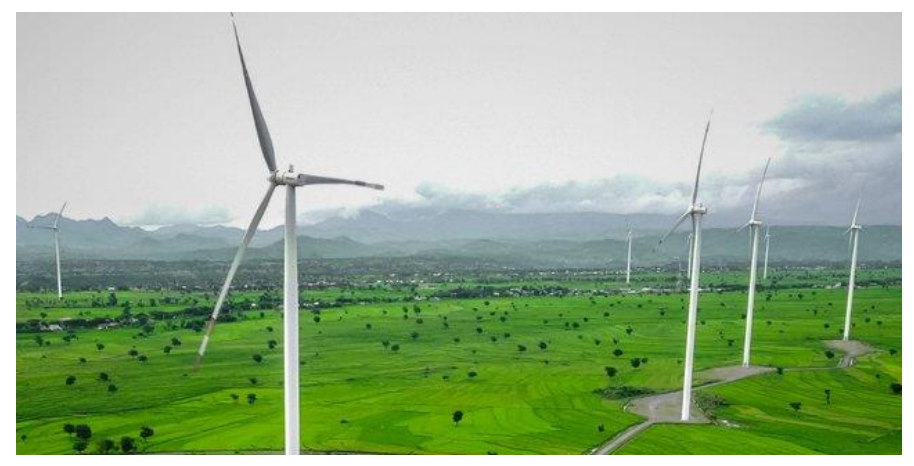

Fig. 3. Wind Power Plant in Jeneponto, South Sulawesi.

The power plant in Jeneponto is currently the result of phase 1 of the wind power plant project at that location. The government is committed to developing the project into phase 2 because the site is considered to have great potential to increase renewable and sustainable energy production and cover the national electricity needs, especially in Eastern Indonesia.

The idea and practice of implementing renewable and sustainable energy projects is a new stage of awareness of policymakers in terms of the importance of the sustainable view being implemented for the sustainability of people's lives [18].

\section{Conclusion}

Renewable energy is not just an idea but a practical activity that the central government needs to implement to ensure sustainability. In realizing the concepts of renewable and sustainable energy, the wind power plant becomes a national project that is recognized. Although indeed, the project can take place if the local government can provide facilities and promote the region's potential so that there are opportunities that can be realized.

The conceptualization of investment paradiplomacy facilitates the involvement of local governments in national projects with significant capital investments originating from abroad. This conceptualization emphasizes the importance of local government involvement in the framework of investment and diplomacy. In addition, this conceptualization framework is supported by available regulations so that the hope of realizing renewable and sustainable energy in Indonesia can be implemented and impact technology transfer.

All authors are grateful to the Lembaga Penelitian, Pengembangan dan Pengabdian Kepada Masyarakat, Universitas Muhammadiyah Makassar, Indonesia, for funding this study through an International Collaborative Research Grant with Contract Number: 004/KONTRPENL/PENGABD/IV/1442/2021. We would also like to thank the University of Dar es Salaam in Tanzania for their collaboration through the research and publishing process.

\section{References}

1. N. H. Afgan, D. Al Gobaisi, M. G. Carvalho, and M. Cumo, Renew. Sustain. Energy Rev. 2, 235 (1998)

2. S. Rassanjani, A. Harakan, P. Pintobtang, and K. Jermsittiparsert, Int. J. Innov. Creat. Chang. 7, 104 (2019)

3. T. Urmee, D. Harries, and A. Schlapfer, Renew. Energy 34, 354 (2009)

4. W. G. Santika, M. Anisuzzaman, Y. Simsek, P. A. Bahri, G. M. Shafiullah, and T. 
Urmee, Energy 196, 117100 (2020)

5. O. T. Winarno, Y. Alwendra, and S. Mujiyanto, in 2016 IEEE Int. Conf. Renew. Energy Res. Appl. (IEEE, 2016), pp. 270-272

6. I. P. Riasa, R. S. Hartati, I. B. G. Manuaba, and D. A. S. Santiari, Maj. Ilm. Teknol. Elektro 19, 27 (2020)

7. D. Lestari, J. Kaji. Sos. Dan Budaya 3, (2019)

8. A. Hidayatno, A. R. Destyanto, and C. A. Hulu, Energy Procedia 156, 227 (2019)

9. M. Jefferson, Renew. Energy 31, 571 (2006)

10. S. Paquin, Glob. Dipl. 49 (2019)

11. A. Harakan, Paradiplomasi Investasi (Samudra Biru, Yogyakarta, 2020)

12. N. Markovska, V. Taseska, and J. Pop-Jordanov, Energy 34, 752 (2009)

13. A. R. Amelia, Katadata (2017)

14. D. H. Barus and R. Dalimi, in 2020 Int. Conf. Electr. Commun. Comput. Eng. (IEEE, 2020), pp. 1-6

15. A. Arief, M. B. Nappu, and A. Sultan, IOP Conf. Ser. Earth Environ. Sci. 473, 012105 (2020)

16. S. M. Said, Y. S. Akil, and M. H. Muzakir, in (2019), p. 030085

17. I. C. Gunadin, Safrizal, M. Rosyadi, A. Siswanto, Syukriyadin, Z. Muslimin, and Gassing, in 2020 1st Int. Conf. Inf. Technol. Adv. Mech. Electr. Eng. (2020), pp. $106-110$

18. I. Siksnelyte, E. Zavadskas, D. Streimikiene, and D. Sharma, Energies 11, 2754 (2018) 